\title{
CLIMATE CHANGE AND AGRICULTURE PAPER Modelling of maize production in Croatia: present and future climate
}

\author{
V. VUČETIĆ \\ Meteorological and Hydrological Service, Grič 3, HR-10000 Zagreb, Croatia \\ (Revised MS received 13 May 2010; Accepted 10 June 2010; First published online 16 November 2010)
}

\begin{abstract}
SUMMARY
Maize is one of the most important agricultural crops in Croatia, and was selected for research of the effect of climate warming on yields. The Decision Support System for the Agrotechnology Transfer model (DSSAT) is one of the most utilized crop-weather models in the world, and was used in this paper for the investigation of maize growth and production in the present and future climate. The impact of present climate on maize yield was studied using DSSAT 4.0 with meteorological data from the Zagreb-Maksimir station covering the period 1949-2004. Pedological, physiological and genetic data from a 1999 field maize experiment at the same location were added. The location is representative of the continental climate in central Croatia. The linear trends of model outputs and the non-parametric Mann-Kendall test indicate that the beginning of silking has advanced significantly by $1 \cdot 4$ days/decade since the mid-1990s, and maturity by $4 \cdot 5$ days/decade. It also shows a decrease in biomass by $122 \mathrm{~kg} / \mathrm{ha}$ and in maize yield by $216 \mathrm{~kg} / \mathrm{ha}$ in 10 years.

Estimates of the sensitivity of maize growth and yield in future climates were made by changing the initial weather and $\mathrm{CO}_{2}$ conditions of the DSSAT 4.0 model according to the different climatic scenarios for Croatia at the end of the 21 st century. Changed climate suggests increases in global solar radiation, minimal temperature and maximal temperature $\left(\times 1 \cdot 07,2\right.$ and $4{ }^{\circ} \mathrm{C}$, respectively), but a decrease in the amount of precipitation $(\times 0 \cdot 92)$, compared with weather data from the period 1949-2004. The reduction of maize yield was caused by the increase in minimal and maximal temperature and the decrease in precipitation amount, related to the present climate, is 6,12 and $3 \%$, respectively. A doubling of $\mathrm{CO}_{2}$ concentration stimulates leaf assimilation, but maize yield is only $1 \%$ higher, while global solar radiation growth by $7 \%$ increases evapotranspiration by $3 \%$. Simultaneous application of all these climate changes suggested that the maize growth period would shorten by c. 1 month and maize yield would decrease by $9 \%$, with the main reason for maize yield reduction in Croatia being due to extremely warm conditions in the future climate.
\end{abstract}

\section{INTRODUCTION}

Climate changes have different intensity in different regions and so their impact on agricultural production varies. Thus, there is a need to research the impact of climate change on agriculture at national and regional levels. The impact of weather on crop growth,

To whom all correspondence should be addressed. Email: vucetic@cirus.dhz.hr development and yield can be best represented by crop-weather models, which facilitate the study of the relationship between weather, climate and crop yield. These models can be empirical-statistical or dynamicdeterministic. The empirical-statistical models use regression methods, while the dynamic-deterministic ones require morphological and physiological plant observations and meteorological measurements. Currently, it is the dynamic-deterministic models that are mostly used for estimating yield and productivity, 
leading to better control and management of agroecological systems, and also to better understanding of the cause-effect relationship in the soil-plant-atmosphere system. The main application of crop models is in the study of the impact of climate change on crop production, whereas the operational application focuses on crop yield forecasting (Eitzinger et al. 2008, 2009).

The aim of the U.S.A. IBSNAT project (International Benchmark Sites Network for Agrotechnology Transfer), which started in 1982, was to develop a computer simulation method that would be widely applicable in farming, environmental protection and economics (Tsuji \& Balas 1993). The Decision Support System for Agrotechnology Transfer (DSSAT) project (Hoogenboom et al. 1995) was developed within IBSNAT, which resulted in the DSSAT computer programme for PCs being made available to as many users as possible. The DSSAT programme for different crop types connects crop type, soil and weather conditions in a single procedure. It includes the main crop types intended for human consumption, divided into three groups: cereals and maize, leguminous plants and root and tuber crops. Each crop group has its own basic simulation model, which is then adapted to a particular crop. The most widely used are the simulation models for maize and wheat, under the common name of CERES (Crop-Environment Resource Synthesis). The CERES models for maize and wheat are some of the most frequently applied crop-weather models in the world, not just in Europe, and this justified its choice in this work.

Maize and winter wheat are the most important agricultural crops in Croatia. Agricultural land amounts to 0.56 of the Croatian landmass and in the period 1998-2007, maize was produced on 0.32 of the arable area, winter wheat on 0.21 and other cereals on $0 \cdot 13$ (Šimanović et al. 2008).

The maize vegetation period in Croatia spans the warm season, from May to October; therefore, unlike, for example, winter wheat, maize growth and yield are not directly affected by snow cover. Most studies on the impact of climate change on maize production have dealt with agronomy but this paper will emphasize research from the meteorological aspect. Crop-weather models are not widely used in Croatia and this paper will help raise awareness of the importance of such applications for a better understanding of the effect of climate changes on agriculture.

\section{MATERIALS AND METHODS}

\section{Meteorological, maize phenological and yield data}

The meteorological data used by the DSSAT model are daily values of maximal and minimal air temperature, the amount of precipitation and the global

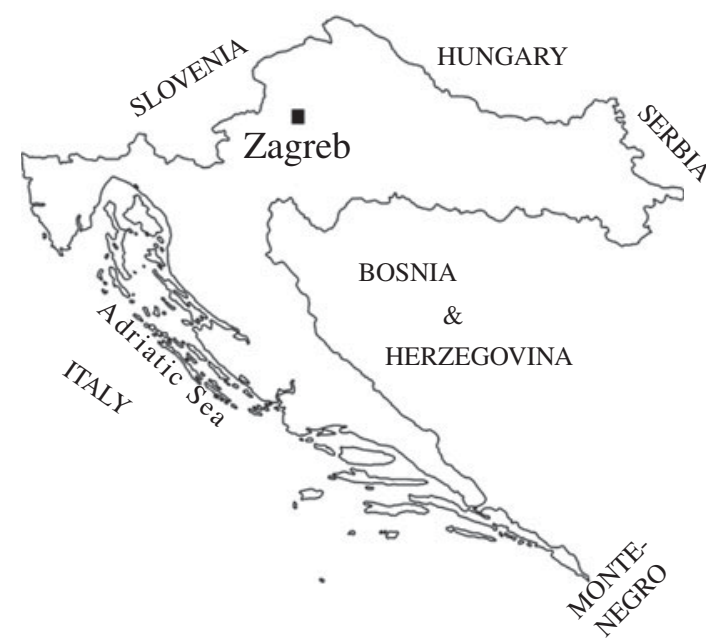

Fig. 1. Location of Zagreb City in Croatia.

solar radiation. The field experiment was carried out at the farm of the Zagreb University Faculty of Agriculture in 1999, and the meteorological data used in the analysis were taken from the nearest meteorological station, Zagreb-Maksimir $\left(45^{\circ} 49^{\prime} \mathrm{N}, 16^{\circ} 2^{\prime} \mathrm{E}\right.$, $123 \mathrm{~m}$ asl), located at about $650 \mathrm{~m}$ from the field experiment site (Fig. 1). For the sensitivity analysis of weather conditions on maize production in the present climate, long-term time series of daily meteorological data were used for the period 1949-2004. The global solar radiation measurement at Zagreb-Maksimir covered too short a period for the necessary analysis, and data were taken from the Zagreb-Grič station $\left(45^{\circ} 49^{\prime} \mathrm{N}, 15^{\circ} 59^{\prime} \mathrm{E}, 157 \mathrm{~m}\right.$ asl $)$ for the period 1949 1986 and the Zagreb-Horvatovac station $\left(45^{\circ} 50^{\prime} \mathrm{N}\right.$, $16^{\circ} 0^{\prime} \mathrm{E}, 182 \mathrm{~m}$ asl) for the period $1987-2004$. These meteorological data are representative of the continental climate in central Croatia, with a mean annual air temperature of $10 \cdot 6^{\circ} \mathrm{C}$ and a precipitation amount of $856 \mathrm{~mm}$.

For the validation of the DSSAT model, long-term time series of maize phenological stages were used from the Božjakovina phenological station $\left(45^{\circ} 49^{\prime} \mathrm{N}\right.$, $16^{\circ} 18^{\prime} \mathrm{E}, \quad 110 \mathrm{~m}$ asl) for the period $1980-2004$. Božjakovina is about $20 \mathrm{~km}$ to the east of the Zagreb-Maksimir station.

Historical data for the entire Croatian area for the period 1885-2008 were used to estimate the variability of total maize yield and maize-planted area in Croatia (Stipetić 1991; Šimanović et al. 2008).

\section{Soil data}

In accordance with IBSNAT recommendations $(1990 a, b)$, samples of the vertical pedological profile were taken for the chemical and physical analysis of the soil about 2 weeks before sowing, which was on 
3 May 1999. The analyses were performed at the Pedology Department of the Faculty of Agriculture in Zagreb. The physical analysis by pedological profile layers determined the required pedological data: water content, field capacity, maximal saturation content, moist bulk density and wilting point. Chemical analyses gave the soil $\mathrm{pH}$ values per layer, the proportion of humus, ammonia, organic and total carbon, the ratio of nitrate in moist and dry soil and the mass of phosphorus and potassium. According to the current Croatian soil classification, the soil used to carry out the experiment belongs to the enteric brown soil type. Medium silt loam was determined by mechanical soil analysis. All measured soil data are presented in Vučetić (2006).

\section{Field experiment}

The field experiment at the farm of the Faculty of Agriculture in Zagreb lasted from 3 May to 16 October 1999. One of the aims was to study how different weather conditions from year to year changed the maize grain yields despite constant practice management and soil conditions. The 1999 field experiment was managed following typical local practices, with only one 'treatment' and without tile drainage or irrigation. In Croatia, maize is not irrigated and soil is watered only by precipitation. Therefore, it was assumed that in the DSSAT model only meteorological conditions differed from year to year in the period 1949-2004, whereas all other initial conditions remained constant. Thus, temporal maize yield variability over different weather conditions has been assessed.

In the autumn and spring 1999 field experiments, $248 \mathrm{~kg} \mathrm{~N} / \mathrm{ha}$ was applied to the soil. The autumn fertilization (25 November 1998) was applied via deep furrow $(0 \cdot 25-0 \cdot 30 \mathrm{~m})$ and consisted of $450 \mathrm{~kg}$ of NPK fertilizer and $350 \mathrm{~kg}$ of urea. Spring fertilization was carried out on 15 April 1999 (300 kg of NPK) and 25 May 1999 (100 kg of limestone ammonium nitrate (KAN)). The maize cultivar PIO 3901 was planted to enable the results to be compared with research results in neighbouring countries. The size of the area sown was $8.5 \times 20 \mathrm{~m}$, which allowed for 12 rows of maize at $0.7 \mathrm{~m}$ row spacing. Plants were $0.19 \mathrm{~m}$ apart within each row and plant density was 80000 plants/ha. Sowing depth was $50 \mathrm{~mm}$. As per IBSNAT requirements (1990a) three biomass harvests and a final harvest were carried out. The biomass consists of the stem, leaves, leaf sheath, ear and husk, while yield is the grain yield. The determination of the moist matter mass, the drying of particular plant parts, the measuring of their dry matter and the chemical analyses were performed at the Special Plant Production Department of the Faculty of Agriculture in Zagreb. All measured crop data are presented in Vučetić (2006).
Input data for the DSSAT model also include genetic coefficients based on the maize phenological phases. $\mathrm{P} 1$ is the growing degree-day $\left(8^{\circ} \mathrm{C}\right.$ temperature threshold) from seedling emergence to the end of the juvenile phase, P2 is the photoperiod sensitivity coefficient, P5 is the growing degree-day $\left(8^{\circ} \mathrm{C}\right.$ temperature threshold) from silking to physiological maturity, G2 is the maximum kernel number per plant and $\mathrm{G} 3$ is the potential kernel growth rate $(\mathrm{mg} / \mathrm{kernel} /$ day).

\section{DSSAT model}

The DSSAT model for maize (Jones \& Kiniry 1986; Ritchie et al. 1990; Hoogenboom 2000; Jones et al. 2003), besides simulating maize growth, development and yield also assesses the commencement of the phenological phases that depend on genetic coefficients and weather conditions, leaf, stem and root growth, the development and growth of vegetative and reproductive organs depending on the phenological phases, soil water balance and water use by crop, soil nitrogen transformation, uptake by the crop and partitioning among plant parts. By including nitrogen and water balance in the model, it is possible to optimally use fertilizers and irrigation (where available) to realize nutrition and water storage in the plant. Thus, in the last version of the DSSAT 4.0 Cropping System Model (CSM) the different modules individually simulate the various processes that affect the land unit including plant growth, soil processes, soil-plant-atmosphere interface and management practice (Jones et al. 2003).

In this paper, the DSSAT 4.0 model has been used for the estimation of maize production in the present and changed climate. In order to investigate the sensitivity of weather conditions on maize growth and yield in the present climate, the pedological conditions, maize genetic conditions and soil management were assumed to be the same as in the 1999 typical field experiment. Thus, in the DSSAT 4.0 model calculation, the Zagreb meteorological data were changed year by year during the 1949-2004 period. This 56-year time series was used to estimate the beginning of silking and maturity dates, grain yield, kernel mass, aboveground biomass, maximum leaf area index (LAI), grain $\mathrm{N}$ and total $\mathrm{N}$ uptake. As the DSSAT 4.0 model includes a module of water balance, output data also included evapotranspiration, evaporation, soil evaporation and runoff. Then, a linear trend analysis was applied to the output results to determine the climate and maize production variability in Croatia in the present climate, in the period 1949-2004.

\section{Statistical analysis}

One of the methods for estimating the existence of a significant trend is the non-parametric Mann-Kendall 

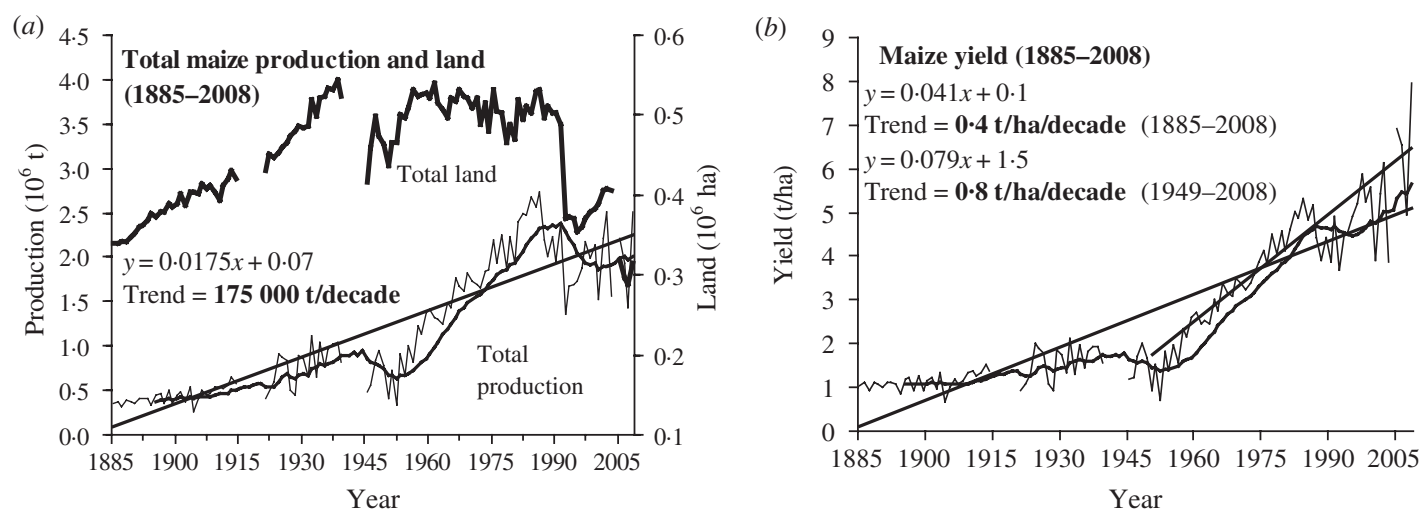

Fig. 2. (a) Long-term time series of total maize production $\left(10^{6} \mathrm{t}\right)$ and area planted to maize $\left(10^{6} \mathrm{ha}\right)$ and $(b)$ mean maize yield (t/ha) as well as linear trends and 5-year running averages of total and mean maize yield in Croatia during the period 1885-2008. Linear trends are significant at $P<0 \cdot 05$.

rank test, based on the values of individual elements of the series and the position of these elements in the series (Mitchell et al. 1966). If a linear trend exists, the values should increase or decrease chronologically. For significant linear trends $(P<0 \cdot 05)$, Sneyers $(1990)$ progressive analysis was used for determining the beginning of a linear trend and its significance.

A linear regression analysis of predicted maize phenological stages was done on the observed phenological data. For both statistical analyses, the STATISTICA 6.0 statistical package was used.

\section{Climate scenarios}

In order to investigate the sensitivity of maize production in future climate, the initial weather and $\mathrm{CO}_{2}$ conditions of the DSSAT model were modified using the results of the different climatic scenarios for Croatia at the end of the 21st century (Vučetic 2008). The climate change scenarios were prepared by the pattern-scaling technique using the following global climate models (GCMs): ECHAM4/OPYC3 from the Max-Planck Institute for Meteorology, HadCM3 from the UK Hadley Centre Climate Prediction and Research and CSIRO-Mk2 from the Australian Commonwealth Scientific and Industrial Research Organisation. A validation analysis in the Czech Republic (Dubrovský et al. 2005) showed these GCMbased standardized scenarios to be a good choice for representative climate changes scenarios in the continental climate. Therefore, these GCMs were used for central Croatia. The mean global temperature $\left(T_{\mathrm{G}}\right)$ values were estimated by the one-dimensional climate model MAGICC for a middle-emission scenario (SRES-B2 + A1), combined with intermediate climate sensitivity (change in $T_{\mathrm{G}}=2.5^{\circ} \mathrm{C}$; IPCC-TGCIA 1999, 2007). Thus, the middle increments are based on an average of increments related to a combination of middle climate sensitivity and SRES-B2 emission scenario, and middle climate sensitivity and SRES-A1 emission scenario.

\section{RESULTS}

\section{Trend analysis of long-term maize land and yield data}

Maize production has always been very important in Croatian agriculture. The total arable maize area increased from 350000 ha in 1885 to 550000 ha in the mid-1930s, but the total production was very low (Fig. 2a). Yield was relatively constant up to about 1945 but started to rise in the early 1950s and this growth continued until the beginning of the last war in Croatia (1991-95), when both maize growing area and yield suddenly dropped by $40-50 \%$. Currently, the total arable maize area amounts to $c .300000$ ha with a $2 \mathrm{Mt}$ grain produced. The linear trend in 10 -year periods indicates a significant increase in grain yield (by $0.8 \mathrm{t} / \mathrm{ha}$ ) for the period 1949-2008, which is faster than in the period 1885-2008 (Fig. 2b).

\section{Analysis of meteorological and maize phenological data}

The mean monthly temperature regime from March to October 1999 was characterized by a warmer period than the 1961-90 norm; in particular, it was very warm in March and extremely warm in September (Table 1; Katušin 2000). The positive deviation of mean monthly temperature in 1999 was mainly associated with a mean minimal temperature above normal. The previously mentioned months were also dry. May was rainy, but the summer precipitation amount was average.

During maize growth and development, daily weather variations are more important than monthly variations; the daily cycles of precipitation and 
Table 1. Mean monthly and annual global solar radiation $(S R)$, maximal $\left(t_{\max }\right)$ and minimal temperature $\left(t_{\min }\right)$ and precipitation amount (Pr) for Zagreb-Maksimir during the period 1949-2004 and in 1999. Also given is a comparison of monthly and annual mean air temperature $(t)$ and precipitation amount $(P r)$ in central Croatia in 1999, compared with 1961-90, according to Katušin (2000). Temperature: C, cold; N, normal; W, warm; VW, very warm; $E W$, extremely warm. Precipitation: $D$, dry; $N$, normal; $R$, rainy

\begin{tabular}{|c|c|c|c|c|c|c|c|c|c|c|}
\hline \multirow[b]{2}{*}{ Month } & $\mathrm{SR}\left(\mathrm{MJ} / \mathrm{m}^{2}\right)$ & $t_{\max }\left({ }^{\circ} \mathrm{C}\right)$ & $t_{\min }\left({ }^{\circ} \mathrm{C}\right)$ & $\operatorname{Pr}(\mathrm{mm})$ & $\mathrm{SR}\left(\mathrm{MJ} / \mathrm{m}^{2}\right)$ & $t_{\max }\left({ }^{\circ} \mathrm{C}\right)$ & $t_{\min }\left({ }^{\circ} \mathrm{C}\right)$ & $\operatorname{Pr}(\mathrm{mm})$ & $t\left({ }^{\circ} \mathrm{C}\right)$ & $\operatorname{Pr}(\mathrm{mm})$ \\
\hline & \multicolumn{4}{|c|}{ 1949-2004 } & \multicolumn{4}{|c|}{1999} & \multicolumn{2}{|c|}{$\begin{array}{c}1961-90 \\
\text { (cf. 1999) }\end{array}$} \\
\hline Jan & $3 \cdot 5$ & $3 \cdot 3$ & $-3 \cdot 8$ & 48 & $3 \cdot 8$ & $3 \cdot 7$ & $-1 \cdot 4$ & 48 & $\mathrm{~N}$ & $\mathrm{~N}$ \\
\hline Feb & 6.5 & $6 \cdot 4$ & $-2 \cdot 3$ & 41 & 6.9 & 6.9 & $-2 \cdot 2$ & 62 & $\mathrm{~N}$ & $\mathrm{R}$ \\
\hline Mar & $10 \cdot 5$ & $11 \cdot 6$ & $1 \cdot 2$ & 51 & $13 \cdot 9$ & 13.9 & $4 \cdot 4$ & 39 & W & D \\
\hline Apr & $14 \cdot 4$ & $16 \cdot 5$ & $5 \cdot 2$ & 64 & $17 \cdot 6$ & 17.6 & $7 \cdot 8$ & 64 & VW & $\mathrm{N}$ \\
\hline May & 18.8 & 21.5 & $9 \cdot 5$ & 77 & $22 \cdot 1$ & $22 \cdot 1$ & 11.4 & 128 & W & $\mathrm{R}$ \\
\hline Jun & $20 \cdot 0$ & $24 \cdot 8$ & $13 \cdot 0$ & 98 & 24.9 & 24.9 & $14 \cdot 5$ & 85 & W & $\mathrm{N}$ \\
\hline Jul & $20 \cdot 6$ & $26 \cdot 8$ & $14 \cdot 4$ & 82 & $26 \cdot 7$ & $26 \cdot 7$ & 16.5 & 101 & W & $\mathrm{N}$ \\
\hline Aug & 17.9 & $26 \cdot 5$ & $14 \cdot 1$ & 87 & $26 \cdot 2$ & $26 \cdot 2$ & 15.6 & 76 & W & $\mathrm{N}$ \\
\hline Sep & $13 \cdot 3$ & $22 \cdot 3$ & $10 \cdot 6$ & 86 & $24 \cdot 4$ & 24.4 & 13.9 & 52 & EW & $\mathrm{D}$ \\
\hline Oct & $8 \cdot 0$ & $16 \cdot 3$ & $6 \cdot 1$ & 76 & $17 \cdot 4$ & $17 \cdot 4$ & 7.9 & 100 & W & $\mathrm{R}$ \\
\hline Nov & 3.9 & $9 \cdot 5$ & 1.9 & 83 & $6 \cdot 4$ & $6 \cdot 3$ & 1.4 & 71 & $\mathrm{C}$ & $\mathrm{N}$ \\
\hline Dec & $2 \cdot 7$ & $4 \cdot 4$ & -1.9 & 63 & $5 \cdot 4$ & $5 \cdot 4$ & $-2 \cdot 1$ & 99 & $\mathrm{~N}$ & $\mathrm{R}$ \\
\hline Year & $8 \cdot 2$ & 15.5 & $5 \cdot 9$ & 856 & $16 \cdot 4$ & $16 \cdot 3$ & $7 \cdot 3$ & 924 & W & $\mathrm{N}$ \\
\hline
\end{tabular}

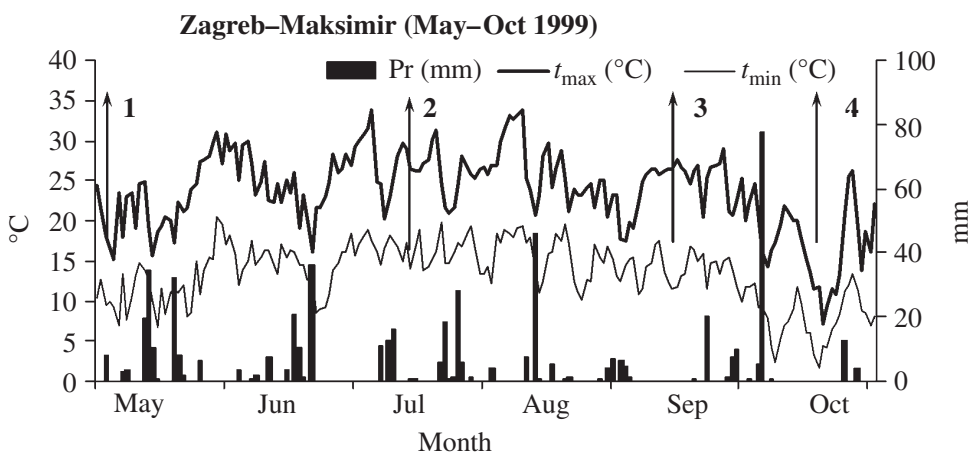

Fig. 3. Daily cycles of precipitation amount $(\operatorname{Pr}, \mathrm{mm})$, maximal $\left(t_{\max },{ }^{\circ} \mathrm{C}\right)$ and minimal temperature $\left(t_{\min },{ }^{\circ} \mathrm{C}\right)$ for Zagreb-Maksimir during the field maize experiment at the farm of the Faculty of Agriculture at Zagreb from May to October 1999. 1, sowing (3 May); 2, silking (15 Jul); 3, maturity (15 Sep); 4, harvest (16 Oct).

maximal and minimal temperatures during the 1999 field experiment are displayed in Fig. 3.

Rainfall amounted to $253 \mathrm{~mm}$ from sowing (0 on the BBCH code of Lancashire et al. 1991; Meier 1997, 3 May) to silking (65 on BBCH code, 15 July), $23 \mathrm{~mm}$ above the 30 -year average and to $150 \mathrm{~mm}$ from silking to physiological maturity $(87$ on $\mathrm{BBCH}$ code when black dot/layer is visible on the base of kernels, 15 September) $9 \mathrm{~mm}$ below the 30-year average. In the sensitive reproductive growth stage, during the second part of July 1999, there was enough rain $(61.6 \mathrm{~mm})$ and the mean minimal and maximal temperatures were 16.2 and $25.9^{\circ} \mathrm{C}$, respectively. The maximal daily temperature was above $30^{\circ} \mathrm{C}$ only on 20 and 21 July 1999 . There were mainly optimal weather conditions for maize fertilization and the beginning of the grain filling phase. The warmest period was between 6 and 10 August 1999 when the daily maximal temperatures were greater than $30^{\circ} \mathrm{C}$ and the maximum temperature of $33.7{ }^{\circ} \mathrm{C}$ occurred on 10 August 1999. After that, $54 \mathrm{~mm}$ rain alleviated these unfavourable temperature conditions.

A comparison of the phenological stages from the 1999 field experiment with the 24-year normal for Božjakovina shows an earlier beginning of milk ripe and wax ripe in 1999 (Table 2). Silking occurred on the same date as the long-term average. 
Table 2. Linear regression coefficients of monthly and annual mean $(t)$, maximal $\left(t_{\text {max }}\right)$ and minimal temperature $\left(t_{\text {min }}\right)$, and precipitation amount $(P r)$ and maximal precipitation $\left(P r_{\max }\right)$ for Zagreb-Maksimir during the period 1949-2004. Significant linear trends $(P \leqslant 0.05)$ are in bold

\begin{tabular}{|c|c|c|c|c|c|}
\hline Month & $t\left({ }^{\circ} \mathrm{C} /\right.$ decade $)$ & $t_{\max }\left({ }^{\circ} \mathrm{C} /\right.$ decade $)$ & $t_{\min }\left({ }^{\circ} \mathrm{C} /\right.$ decade $)$ & $\operatorname{Pr}(\mathrm{mm} /$ decade $)$ & $\operatorname{Pr}_{\max }(\mathrm{mm} /$ decade $)$ \\
\hline Jan & $0 \cdot 40$ & $0 \cdot 34$ & $0 \cdot 58$ & $-2 \cdot 41$ & $-2 \cdot 95$ \\
\hline Feb & $0 \cdot 39$ & $0 \cdot 47$ & $0 \cdot 45$ & $-2 \cdot 26$ & $-2 \cdot 52$ \\
\hline Mar & $0 \cdot 43$ & $0 \cdot 47$ & $0 \cdot 54$ & $1 \cdot 00$ & $-2 \cdot 68$ \\
\hline Apr & 0.03 & -0.08 & $0 \cdot 29$ & $1 \cdot 58$ & $-2 \cdot 81$ \\
\hline May & $0 \cdot 33$ & $0 \cdot 26$ & $0 \cdot 52$ & $-6 \cdot 07$ & $-4 \cdot 82$ \\
\hline Jun & $0 \cdot 19$ & $0 \cdot 12$ & $0 \cdot 38$ & -1.69 & $-5 \cdot 40$ \\
\hline Jul & $0 \cdot 21$ & $0 \cdot 03$ & $0 \cdot 43$ & $-2 \cdot 84$ & $-4 \cdot 87$ \\
\hline Aug & 0.95 & $0 \cdot 22$ & $0 \cdot 65$ & $2 \cdot 48$ & $-4 \cdot 30$ \\
\hline Sep & 0.02 & $-0 \cdot 19$ & $0 \cdot 31$ & $3 \cdot 93$ & $-4 \cdot 53$ \\
\hline Oct & $0 \cdot 16$ & $-0 \cdot 01$ & $0 \cdot 45$ & $7 \cdot 72$ & $-2 \cdot 96$ \\
\hline Nov & $-0 \cdot 01$ & $-0 \cdot 01$ & $0 \cdot 11$ & $-2 \cdot 91$ & $-4 \cdot 90$ \\
\hline Dec & -0.04 & -0.04 & $0 \cdot 07$ & $-3 \cdot 33$ & $-3 \cdot 30$ \\
\hline Year & $0 \cdot 21$ & $0 \cdot 13$ & $0 \cdot 40$ & $-4 \cdot 80$ & $-8 \cdot 16$ \\
\hline
\end{tabular}

Table 3. Mean dates of maize phenological stages (MEAN) and standard deviation (S.D.) for Božjakovina in the period 1980-2004 and for 1999, and for the field experiment (FE) at the farm of the Zagreb Faculty of Agriculture in 1999. The BBCH-code (Biologische Bundesanstalt, Bundessortenamt and Chemical Industry) is a decimal code system used to identify the phenological development stages of a plant (Lancashire et al. 1991; Meier 1997)

\begin{tabular}{|c|c|c|c|c|c|}
\hline $\mathrm{BBCH}$ & Phenological stages & MEAN (date) & S.D. (day) & 1999 & FE \\
\hline 0 & Sowing & $29 \mathrm{Apr}$ & 4 & $28 \mathrm{Apr}$ & 3 May \\
\hline 10 & Emergence & 12 May & 4 & 11 May & 15 May \\
\hline 65 & First silk emerged & $15 \mathrm{Jul}$ & 7 & $9 \mathrm{Jul}$ & $15 \mathrm{Jul}$ \\
\hline 75 & Milk ripe & $13 \mathrm{Aug}$ & 10 & 6 Aug & 5 Aug \\
\hline 85 & Waxy ripe & 31 Aug & 12 & 19 Aug & 20 Aug \\
\hline 87 & Physiological maturity & 19 Sep & 16 & $10 \mathrm{Sep}$ & $15 \mathrm{Sep}$ \\
\hline 120 & Harvest & $3 \mathrm{Oct}$ & 12 & $16 \mathrm{Sep}$ & 16 Oct \\
\hline
\end{tabular}

It was important that the 1999 field experiment experienced 'typical' weather justified its use for investigating the impact of present and future climate changes. In order to establish the climate variations in present climate, the linear trends of monthly temperature and precipitation were defined for the Zagreb-Maksimir station for the period 1949-2004 (Table 3). The linear trend analysis and MannKendall text indicate that the greatest significant increase in mean monthly temperature in August $\left(0.95^{\circ} \mathrm{C} /\right.$ decade $)$ is mainly the result of a significant increase in minimal temperature. In general, a significant positive trend of monthly minimal temperature occurred from March to October and in January and of maximal temperature only in March and May. The monthly minimal temperature increased faster than the maximal and there was a significant annual increase in minimal temperature $\left(0.4^{\circ} \mathrm{C} /\right.$ decade $)$. There was no significant linear trend in monthly or annual precipitation in the period 1949-2004.

\section{Model calibration and validation}

The calibration consisted of determining the five genetic coefficients to adjust phenological stage timing and yield parameters. After each run of the DSSAT 4.0 model, the coefficients controlling silking and maturity dates were readjusted automatically. The following genetic coefficients have been determined for the PIO3901 hybrid: $\mathrm{P} 1=200{ }^{\circ} \mathrm{C} ; \mathrm{P} 2=0 \cdot 10$ and $\mathrm{P} 5=740^{\circ} \mathrm{C} ; \mathrm{G} 2=625$ kernel/ear and $\mathrm{G} 3=11 \mathrm{mg} /$ kernel/day.

The variables used for validation were silking and maturity dates, grain yield, kernel mass, maximum LAI, biomass, harvest index, $\mathrm{N}$ grain and total $\mathrm{N}$ uptake. The predicted values of the DSSAT 4.0 model, derived from the meteorological, pedological, physiological and cultivation data measured during the 1999 field experiment are presented in Table 4. The performance validation of the DSSAT 4.0 was also done through a linear correlation between a 
Table 4. Predicted values according to the DSSAT 4.0 models and the observed values collected during the field experiment and from the pedological profile at the farm of the Faculty of Agriculture at Zagreb in 1999

\begin{tabular}{|c|c|c|c|}
\hline Description & Observed & Predicted & $\begin{array}{l}\text { Predicted/ } \\
\text { Observed }\end{array}$ \\
\hline \multicolumn{4}{|c|}{ Sowing date: 3 May 1999} \\
\hline $\begin{array}{l}\text { Silking (day of } \\
\text { year) }\end{array}$ & 196 & 197 & $1 \cdot 01$ \\
\hline $\begin{array}{l}\text { Maturity (day of } \\
\text { year) }\end{array}$ & 258 & 254 & $0 \cdot 98$ \\
\hline Grain yield (t/ha) & $13 \cdot 1$ & $11 \cdot 9$ & $0 \cdot 90$ \\
\hline Kernel mass (g) & $0 \cdot 347$ & $0 \cdot 483$ & $1 \cdot 39$ \\
\hline$\underset{\left(\mathrm{m}^{2} / \mathrm{m}^{2}\right)}{\operatorname{Maximum}} \mathrm{LAI}$ & $4 \cdot 8$ & $4 \cdot 6$ & $0 \cdot 96$ \\
\hline Biomass (t/ha) & $22 \cdot 4$ & $21 \cdot 8$ & 0.97 \\
\hline $\mathrm{N}$ grain $(\mathrm{kg} / \mathrm{ha})$ & 138 & 180 & $1 \cdot 30$ \\
\hline $\mathrm{N}$ uptake (kg/ha) & 177 & 202 & $1 \cdot 14$ \\
\hline Harvest index & $0 \cdot 58$ & 0.54 & $0 \cdot 93$ \\
\hline
\end{tabular}

long-term time series of predicted maize silking and maturity dates, and the observed phenological data of maize silking and maturity dates in the Zagreb area in the period 1980-2004 (Fig. 4).

\section{Predicted mean values of maize components}

According to the theoretical calculations achieved by the DSSAT 4.0 model for the period 1949-2004, silking starts, on average, on 19 July, with a standard deviation of 6 days (Table 5). The beginning of silking and maturity were exceptionally early in 1950, 2000 and 2003, which were extremely warm years in Croatia.

Physiological maturity starts usually 70 days after silking with an 18-day deviation from average. The mean grain yield is about $12.4 \mathrm{t} / \mathrm{ha}$ and the average biomass is $22 \cdot 2 \mathrm{t} / \mathrm{ha}$. Both these predicted values can deviate by $c .1 \cdot 5 \mathrm{t} / \mathrm{ha}$. In 1952, 2001 and 2003, the yield was under $9 \cdot 0 \mathrm{t} / \mathrm{ha}$.

In the Zagreb area, the average kernel mass has been estimated at $0.46 \mathrm{~g}$ and the average LAI at $4.4 \mathrm{~m}^{2} / \mathrm{m}^{2}$. The DSSAT 4.0 model simulated the mean amount of nitrogen in harvest seeds to be $183 \mathrm{~kg} / \mathrm{ha}$ and the total nitrogen uptake during the vegetation period to be $257 \mathrm{~kg} / \mathrm{ha}$.

\section{Linear trends of maize yield components in present climate}

To determine the relationships of major changes in maize growth, development and yield over the 56-year period with weather conditions, the linear trends of particular predicted maize components were analysed. Silking started significantly earlier ( $-1 \cdot 4$ days/ decade), as did the achievement of maturity ( $-4 \cdot 5$ days/decade; Fig. 5 and Table 6). There was a significant linear decrease in maize yield $(-216 \mathrm{~kg} /$ ha/decade). There was a slight decrease in kernel mass $(-0.01 \mathrm{~g} / \mathrm{decade})$, aboveground biomass $(-122 \mathrm{~kg} /$ decade) and harvest index ( $-0 \cdot 01 /$ decade). There was no significant trend in kernel number/ear and maximum LAI. The increase in total nitrogen uptake in maize by $0.6 \mathrm{~kg} / \mathrm{ha}$ and the decrease in nitrogen in harvested seeds by $-0.03 \mathrm{~kg} / \mathrm{ha} / \mathrm{decade}$ is not significant in the Zagreb area (Table 6). A positive trend in evapotranspiration and soil evaporation $(c .3 \mathrm{~mm} /$ decade) and in runoff $(0.6 \mathrm{~mm} /$ decade $)$ has been noticed during the vegetation period. An increase in runoff could cause a significant increase in soil erosion, which is mainly associated with the cultivation of root and row crops, especially maize in Central Europe (Klik \& Eitzinger 2010).

A significant earlier beginning of silking $(P=0.0027)$ and physiological maturity $(P=0.0003)$ started in 1998 and 1996, respectively, while a significant decrease in grain yield $(P=0 \cdot 0418)$ commenced in 2002 (Fig. 5).

\section{Sensitivity analysis of maize production in future climate}

Changing the initial weather and $\mathrm{CO}_{2}$ conditions of the DSSAT model, according to the results of different climate scenarios at the end of 21 st century (Vučetić 2008), the sensitivity of maize growth and yield in the future climate was analysed. In the future climate, in central Croatia, global solar radiation is projected to increase by $c$. 1.07 times the present values (period 1949-2004), minimal temperature by $2{ }^{\circ} \mathrm{C}$ and maximal temperature by $4{ }^{\circ} \mathrm{C}$, but the amount of precipitation is projected to decrease by 0.92 of present values.

Separate increases in minimal and maximal temperature and a decrease in precipitation amount, compared with present (1949-2004) climate, led to a prediction of maize yields being reduced by 6,12 and $3 \%$, respectively (Fig. 6). A doubling of $\mathrm{CO}_{2}$ concentration stimulated leaf assimilation, but maize yield was only $1 \%$ higher. Global solar radiation growth by $7 \%$ increases evapotranspiration by $3 \%$. By applying all the modifications simultaneously, with the same practical management and hybrids as used currently, the length of the maize-growing period would be shorter by about a month and the maize grain yield would be reduced by $9 \%$ compared to the long-term average.

\section{DISCUSSION}

\section{Weather conditions and field experiment}

Despite the decrease in total arable maize area in Croatia, the significant increase in maize grain yield 
Table 5. Predicted mean (MEAN), maximum (MAX) and minimum (MIN) values of particular maize parameters according to the DSSAT 4.0 model based on the Zagreb-Maksimir meteorological data for the period 1949-2004. S.D. is the standard deviation and AMPL is the amplitude

\begin{tabular}{lcccccrrr}
\hline \hline 1949-2004 & $\begin{array}{c}\text { Silking } \\
\text { date }\end{array}$ & $\begin{array}{c}\text { Maturity } \\
\text { date }\end{array}$ & $\begin{array}{c}\text { Grain yield } \\
(\mathrm{t} / \mathrm{ha})\end{array}$ & $\begin{array}{c}\text { Kernel } \\
\text { mass }(\mathrm{g})\end{array}$ & $\begin{array}{c}\text { Max. LAI } \\
\left(\mathrm{m}^{2} / \mathrm{m}^{2}\right)\end{array}$ & $\begin{array}{c}\text { Biomass } \\
(\mathrm{t} / \mathrm{ha})\end{array}$ & $\begin{array}{c}\text { Grain N } \\
(\mathrm{kg} / \mathrm{ha})\end{array}$ & $\begin{array}{c}\text { Total N uptake } \\
(\mathrm{kg} / \mathrm{ha})\end{array}$ \\
\hline MEAN & 19 Jul & $26 \mathrm{Sep}$ & $12 \cdot 4$ & $0 \cdot 46$ & $4 \cdot 4$ & $22 \cdot 2$ & 183 & 257 \\
S.D. & 6 & 18 & $1 \cdot 48$ & $0 \cdot 06$ & $0 \cdot 3$ & $1 \cdot 5$ & 16 & 14 \\
MAX & 2 Aug & 13 Nov & $14 \cdot 4$ & $0 \cdot 60$ & $5 \cdot 0$ & $24 \cdot 7$ & 218 & 284 \\
MIN & 1 Jul & 17 Aug & $8 \cdot 3$ & $0 \cdot 30$ & $3 \cdot 7$ & $17 \cdot 6$ & 146 & 232 \\
AMPL & 32 & 88 & $6 \cdot 1$ & $0 \cdot 29$ & $1 \cdot 3$ & $7 \cdot 1$ & 72 & 52 \\
\hline \hline
\end{tabular}
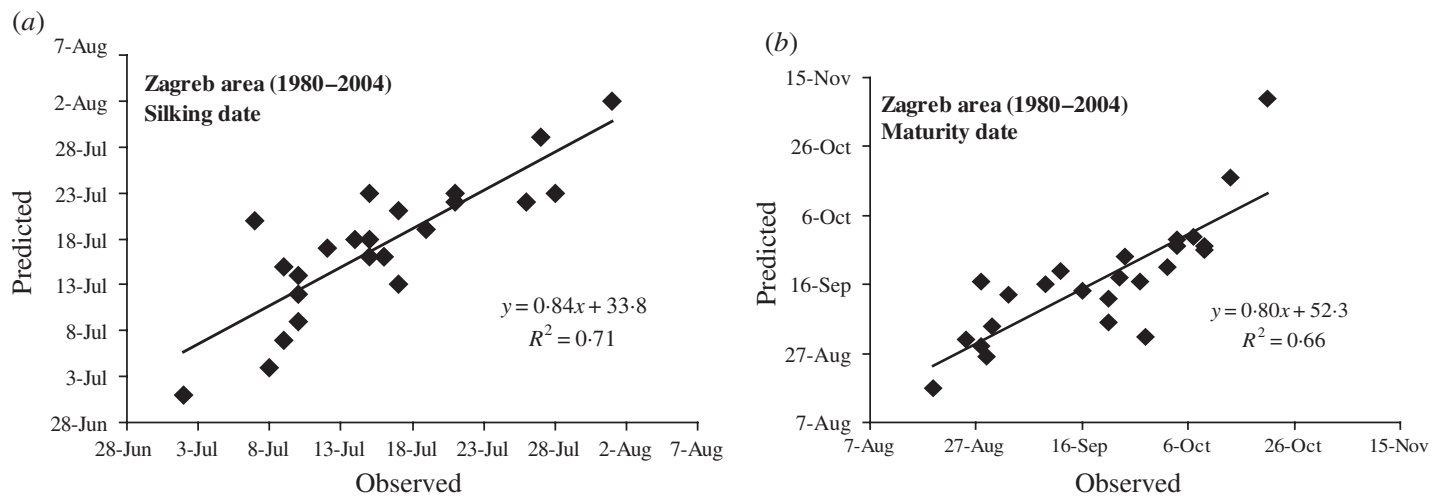

Fig. 4. Correlation between observed and predicted silking and maturity dates for maize in the Zagreb area during the period 1980-2004.

(Fig. 2) is the result of sowing late-maturing hybrids with longer growing periods combined with improved agricultural management. For example, in 2008 the mean grain yield was $c .8 \mathrm{t} / \mathrm{ha}$, which is the maximal yield during the whole period 1885-2008. According to recommendations by Majdak et al. (2007) autumn soil fertilization should be undertaken under a deep furrow $(0 \cdot 25-0 \cdot 30 \mathrm{~m})$ and spring fertilization should be carried out before sowing and reinforced after emergence. Thus, a grain yield of $10-15 \mathrm{t} / \mathrm{ha}$ requires c. $200-250 \mathrm{~kg} \mathrm{~N} / \mathrm{ha}$. In the 1999 maize field experiment, $248 \mathrm{~kg} / \mathrm{ha}$ were used. As already shown, the weather conditions were good, especially from sowing to silking and the beginning of grain filling. Warm weather, with some drier conditions, from silking to maturity accelerated grain filling and physiological maturity, which took place around 10 days earlier. The DSSAT 4.0 simulation did not suggest the occurrence of water stress during the whole maizegrowing period.

However, the harvest of maize not only depends on weather conditions, but also on human decisions. The best moment for harvest of dry maize grain is when relative humidity is lower than $30 \%$. In order to meet this condition, the 1999 harvest was rather late, on 16 October 1999. Although the first part of September 1999 was dry, heavy rain $(82.6 \mathrm{~mm})$ fell at the beginning of October (Fig. 3) and delayed the onset of the harvest.

Thus, it is considered that the field experiment data were representative of the initial physiological and cultivation data in the study of potential crop production over expected climate change conditions. However, one of the problems in the study of the climate change impact on agricultural production is the lack of model input data, such as crop and soil data, for the long-term period.

\section{Calibration and validation of the DSSAT 4.0}

The predicted values of the DSSAT 4.0 model, derived from the 1999 meteorological data and from the pedological, physiological and cultivation data measured during the 1999 field experiment, are very similar to the observed values: beginning of silking and maturity, maximum LAI and biomass (Table 4). However, the DSSAT 4.0 simulation underestimated the grain yield and harvest index, 
(a)

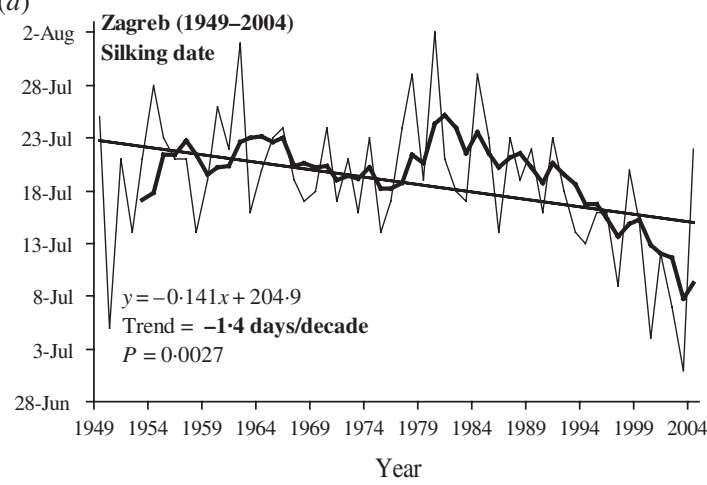

(b)

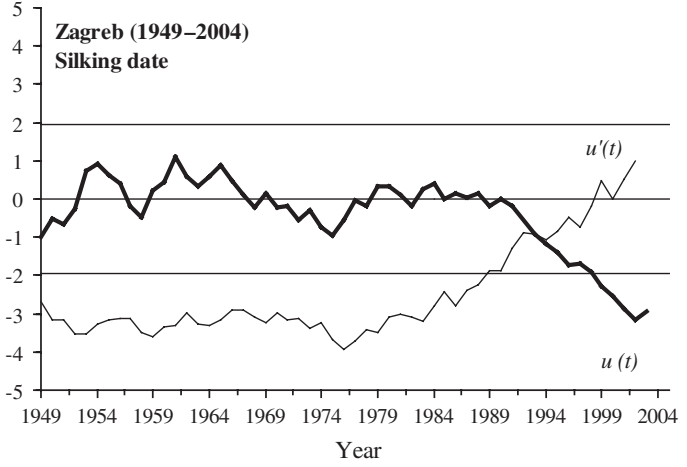

(c)

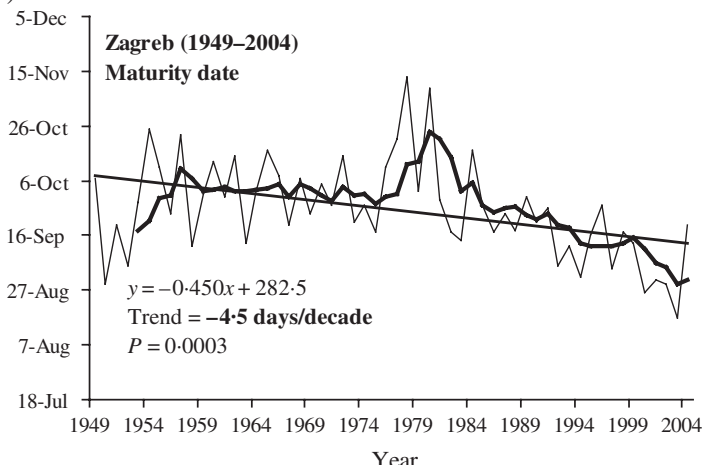

(e)

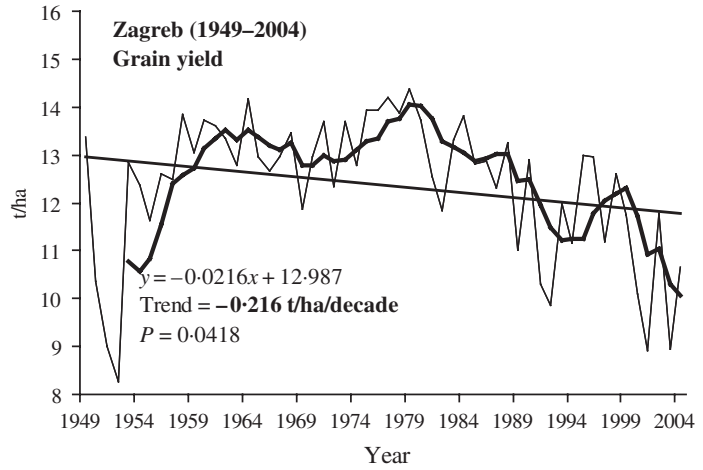

(d)

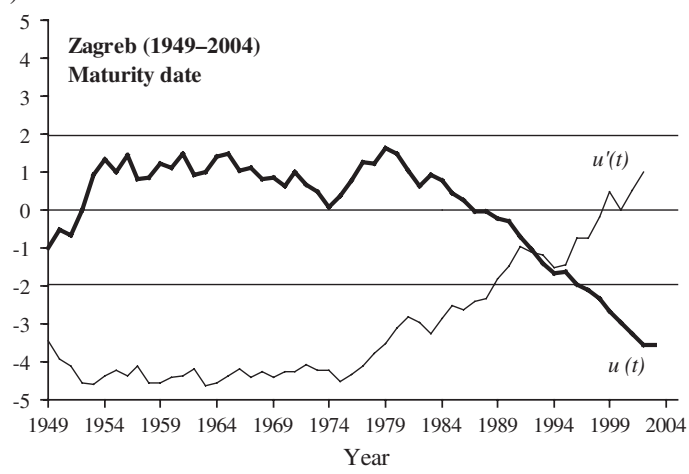

(f)

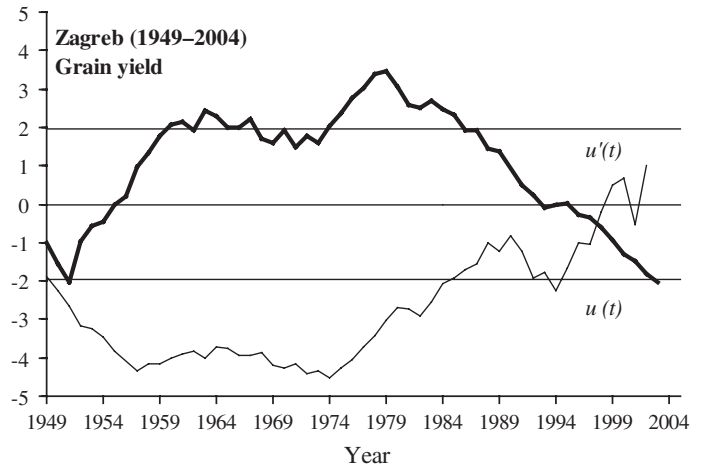

Fig. 5. ( $a, c$ and $e$ ) Predicted time series, significant linear trends $(P<0 \cdot 05)$ and 5 -year running averages of the beginning of silking and maturity (days) and grain yield (kg/ha) according to the DSSAT maize model for Zagreb in the period 1949-2004. $x$ is a number of years $(0,1,2, \ldots, 55)$. $(b, d$ and $f)$ The progressive trend test for the significant linear trend in the beginning of silking and maize maturity (days) and grain yield ( $\mathrm{kg} / \mathrm{ha})$, for the forward series $u(t)$ (thick line) and backward series $u^{\prime}(t)$ (thin line) for Zagreb during the period 1949-2004. The positive $u(t)$ points at an increasing trend, while the negative $u(t)$ points at a decreasing trend. In order to identify the beginning of the possible trend, $u(t)$ has been calculated from the first to the last datum, forming a progressive onward test series. The backward test series $u^{\prime}(t)$ has been formed in the same manner, calculating it from the last to the first term. If there is no trend, the $u(t)$ and $u^{\prime}(t)$ curves overlap several times, whereas in the case of a trend, the intersection point designates the beginning of the trend, becoming significant at $P<0.05$ in case the absolute $u(t)$ exceeds the \pm 1.96 values (thin horizontal lines).

and overestimated kernel mass, grain $\mathrm{N}$ and total $\mathrm{N}$ uptake. This underestimation of predicted grain yield by 0.095 is considered a good assessment because a deviation of up to $0 \cdot 20$ of simulated yield from measured yield is considered good (Alexandrov et al. 2001). 
Table 6. Linear trends of predicted time series of the beginning of silking and maturity (days), grain yield $(\mathrm{kg} / \mathrm{ha})$, kernel mass $(\mathrm{g})$, number of kernel per ear, maximum leaf area index (LAI max, $\mathrm{m}^{2} / \mathrm{m}^{2}$ ), aboveground biomass ( $\mathrm{kg} / \mathrm{ha}$ ), total nitrogen uptake $(\mathrm{kg} / \mathrm{ha}$,) nitrogen in harvest seeds ( $\mathrm{kg} / \mathrm{ha})$, harvest index, evapotranspiration ( $\mathrm{mm})$, evaporation $(\mathrm{mm})$, soil evaporation ( $\mathrm{mm}$ ) and runoff $(\mathrm{mm})$ during the vegetation period according to the DSSAT maize model for Zagreb in the period 1949-2004. Linear trends significant at $P \leqslant 0.05$ are in bold

\begin{tabular}{lc}
\hline \hline Predicted values & Trend (/decade) \\
\hline Silking day & $\mathbf{- 1 \cdot 4}$ \\
Maturity day & $\mathbf{- 4 \cdot 5}$ \\
Grain yield $(\mathrm{t} / \mathrm{ha})$ & $\mathbf{- 0 \cdot 2 1 6}$ \\
Kernel mass $(\mathrm{g})$ & $-0 \cdot 01$ \\
Number of kernel per ear & $-0 \cdot 2$ \\
Maximum LAI $\left(\mathrm{m}^{2} / \mathrm{m}^{2}\right)$ & $0 \cdot 01$ \\
Biomass $(\mathrm{t} / \mathrm{ha})$ & $-0 \cdot 122$ \\
N grain $(\mathrm{kg} / \mathrm{ha})$ & $0 \cdot 0$ \\
Total N uptake $(\mathrm{kg} / \mathrm{ha})$ & $0 \cdot 6$ \\
Harvest index & $-0 \cdot 01$ \\
Evapotranspiration $(\mathrm{mm})$ & $3 \cdot 3$ \\
Evaporation (mm) & $0 \cdot 5$ \\
Soil evaporation $(\mathrm{mm})$ & $2 \cdot 8$ \\
Runoff $(\mathrm{mm})$ & $0 \cdot 6$ \\
\hline \hline
\end{tabular}

\section{Predicted mean values of maize components}

The DSSAT 4.0 model offered a good assessment of maize phenology in the Zagreb area (Fig. 4). The underestimation of predicted grain yield compared with the actual observed yield was linked to a short, but very warm period during grain filling, i.e. to greater amplitude between the maximal and minimal temperature. The DSSAT model seems to indicate a better grain filling rate when the temperature difference between maximal and minimal is minimized (Wilkens \& Singh 2001). As the sensitivity range of these differences strongly influences the predicted values of grain yield, it needs to be evaluated against a model.

Predicted values of phenological stages similar to those in Croatia, have been determined by Hunkar (1994) for Hungary. The beginning of the silking date in Hungary, as calculated by the DSSAT 2.1 model, takes place at the same time as in Croatia. On average, maturity begins about 2 months after silking, i.e. 10 days earlier than in Croatia. The predicted values of grain yield and biomass for Hungary are, on average, smaller by $1700 \mathrm{~kg} / \mathrm{ha}$ than for Croatia. However, the absolute value of grain yield is not so important for research in the climate change impact on crop production - the relative relationship between grain yield in the present and future climate is more important.

\section{Maize production in present and future climate}

Modelling of the impact of climatic changes on maize growth and development indicates a double $\mathrm{CO}_{2}$ effect. Carbon dioxide in the atmosphere directly affects plants by increasing photosynthesis and decreasing transpiration. An increase in $\mathrm{CO}_{2}$ in the atmosphere also changes the weather conditions affecting plant growth. Thus, an increase in air temperature shortens the vegetation period and reduces maize yield, while an increase in solar radiation stimulates not only leaf assimilation but also evapotranspiration. Taking the direct impact of $\mathrm{CO}_{2}$ into consideration, together with its double concentration in the stochastic weather generator Met\&Roll (Dubrovský et al. 2000), resulted in a 9-10\% increase in potential maize yield predicted for the Czech Republic (Žalud \& Dubrovský 2002). The direct and indirect $\mathrm{CO}_{2}$ effects, combined, suggest a $5-14 \%$ increase in potential yield. It is also shown that the increase in the simulated yields of other agricultural crops (e.g. winter wheat, soybean, etc.) for the 21 st century was primarily because of the beneficial influence of the direct $\mathrm{CO}_{2}$ effect (Alexandrov et al. 2002).

It has already been noticed in Croatia that silking and maturity are occurring significantly earlier, and grain yield is significantly decreased, in the present climate. In previous studies (Vučetić 2006, 2008, 2009), it has been shown that different transient climate change scenarios during the 21st century, including only an indirect $\mathrm{CO}_{2}$ effect, gave projections of a shorter growing season (34 days shorter for CSIROMk2, 43 days for ECHAM4/OPYC3 and 44 days for HadCM3) and a reduction in maize yields by 10,8 and $15 \%$, respectively. In this study, using both direct and indirect $\mathrm{CO}_{2}$ effects in a changed climate, the maize-growing period has been predicted to be a month shorter and the maize grain yield reduced by $9 \%$ compared with the present climate. These assessments agree with the results from neighbouring countries. Bacsi \& Hunkar (1994) have come to the conclusion that the growth period of maize in western Hungary in changed climate would be $20-41$ days shorter, which would result in a $7-14 \%$ smaller grain yield. Research in Slovenia shows that on the assumption of a $2{ }^{\circ} \mathrm{C}$ increase in temperature the cultivation area could be raised to a higher altitude (Kajfež-Bogataj 1993, 1996, 1998). It has been predicted that the maize yield at $500 \mathrm{~m}$ under present conditions would correspond to the yield at $900 \mathrm{~m}$ at the end of 21 st century. A sensitivity analysis in the main arable areas of the European Community (Wolf \& van Diepen 1995) reveals that the potential yield of grain maize increases in the northern part of the EC, remains similar in the central part and decreases in the southern part. Drought is the main factor limiting the productivity of crops in southern Europe. For 

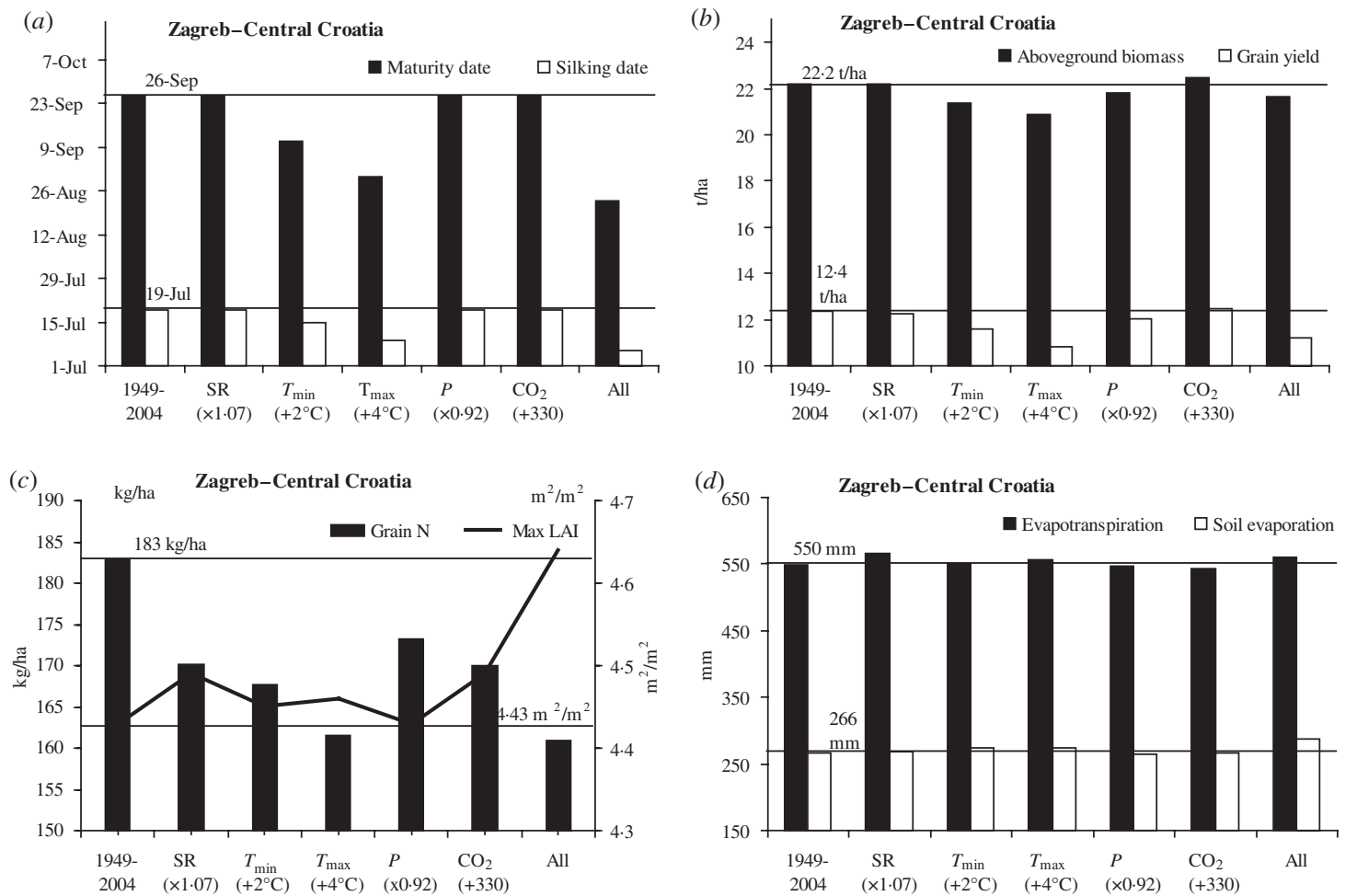

Fig. 6. Comparison between predicted maize parameters, evapotranspiration and soil evaporation in present climate (19492004, thin horizontal lines) and in future climate (bars and thick line) for Zagreb, which is representative of central Croatia.

example, the mean reduction of barley yield by terminal drought was 27\% (González et al. 2010). The Northern Atlantic Oscillation (NAO) exerts a dominant effect on air temperature in Europe and for example in England there has been a significant correlation between the winter NAO and summer climate since the mid-1950s (Atkinson et al. 2008).

This paper confirms that, in the future, Croatia could belong to the area of decreased maize yields. Some adaptation options, such as shifting to an earlier sowing date and selecting hybrids resistant to drought, could be an appropriate response to offset the negative effect of an increase in temperature. For example, using hybrids with a medium growing season would be beneficial for maize productivity in Bulgaria in the changed climate (Alexandrov \& Hoogenboom 2000).

Thus, the main conclusion from this study is that a direct impact of $\mathrm{CO}_{2}$ does not indicate a considerable increase in grain yield in the changed climate in Croatia, whereas extremely warm conditions would have a definite influence on maize yield reduction. Some other crops also have a significant negative response to higher daily maximal temperature, for example, soybean (Zheng et al. 2009).
The experience of farmers and agronomists in central Croatia shows that they have already been adapting maize production to the warmer weather conditions in the last decade. The usual hybrids in central Croatia were hybrids with a medium growing season but nowadays hybrids with a longer growing season are increasingly used. This study could help in optimizing and improving agricultural management in order to adapt for changes in climate and weather conditions in Croatia.

This research has been carried out as part of the project COST Action 734 Impacts of climate change and variability on European agriculture (CLIVAGRI) and Climate variations and changes and response in affected system of the Croatian Ministry of Science, Education and Sport. I am grateful to the Faculty of Agronomy of Zagreb University and the Geophysical Department of the Faculty of Natural Sciences of Zagreb University for their help. I also thank Lučka Kajfež-Bogataj, Tomislav Čosić, Martin Dubrovský, Gordon Y. Tsuji, James R. Kiniry, Josef Eitzinger, Marko Jukić, Marta Hunkar, Marjana Gajić-Čapka, Lidija Srnec, Sabina Thaler and Muhammad Anjum Iqbal for their support. 


\section{REFERENCES}

Alexandrov, V. \& Hoogenboom, G. (2000). The impact of climate variability and change on crop yield in Bulgaria. Agricultural and Forest Meteorology 104, 315-327.

Alexandrov, V., Eitzinger, J. \& Oberforster, M. (2001). Adaptation of crop-weather models in Austria and Bulgaria. In Proceedings of the 5th European Conference on Applications of Meteorology. Budapest, Hungary: European Meteorological Society. CD-ROM.

Alexandrov, V., Eitzinger, J., ČAJić, V. \& Oberforster, M. (2002). Potential impact of climate change on selected agricultural crops in north-eastern Austria. Global Change Biology 8, 372-389.

Atkinson, M. D., Kettlewell, P. S., Poulton, P. R. \& Hollins, P. D. (2008). Grain quality in the Broadbalk Wheat Experiment and the winter North Atlantic oscillation. The Journal of Agricultural Science, Cambridge 146, 541-549.

BACsi, Z. \& HunKar, M. (1994). Assessment of the impacts of climate change on the yields of winter wheat and maize using crop models. Idöjárás 98, 119-134.

Dubrovský, M., ŽAlud, Z. \& ŠTASTNÁ, M. (2000). Sensitivity of CERES-Maize yields to statistical structure of daily weather series. Climatic Change 46, 447-472.

Dubrovský, M., Nemesova, I. \& Kalvova, J. (2005). Uncertainties in climate change scenarios for the Czech Republic. Climate Research 29, 139-156.

Eitzinger, J., Thaler, S., Orlandini, S., Nejedlik, P., Kazandjiev, V., Vucetic, V., Siversten, T. H., Mihailovic, D. T., Lalic, B., Tsiros, E., Dalezios, N. R., Susnik, A., Kersebaum, C. K. C., Holden, N. M. \& Matthews, R. (2008). Agroclimatic indices and simulation models. In Survey of Agrometeorological Practices and Applications in Europe regarding Climate Change Impacts (Eds P. Nejedlik \& S. Orlandini), pp. 15-114. Florence: European Science Foundation.

Eitzinger, J., Thaler, S., Orlandini, S., Nejedlik, P., Kazandjiev, V., Siversten, T.H. \& Mihailović, D. (2009). Applications of agroclimatic indices and process oriented crop simulation models in European agriculture. Idöjárás 113, 1-12.

GonzÁlez, A., Bermejo, V. \& Gimeno, B. S. (2010). Effect of different physiological traits on grain yield in barley grown under irrigated and terminal water deficit conditions. Journal of Agricultural Science, Cambridge $\mathbf{1 4 8 ,}$ 319-328.

Hoogenboom, G. (2000). Contribution of agrometeorology to the simulation of crop production and its application. Agricultural and Forest Meteorology 103, 137-157.

Hoogenboom, G., Tsuji, G. Y., Jones, J. W., Singh, U., Godwin, D. C., Pickering, N. B. \& Curry, R. B. (1995). Decision support system to study climate change impacts on crop production. In Climate Change and Agriculture: Analysis of Potential International Impacts (Eds C. Rosenzweig, L. H. Allen Jr., A. Harper, S. E. Hollinger \& J. W. Jones), ASA Special Publication No. 59, pp. 5175. Madison, WI: American Society of Agronomy.

HunKAR, M. (1994). Validation of crop simulation model CERES-Maize. Idöjárás 98, 37-46.

IBSNAT (1990a). Field and Laboratory Methods for the Collection of the IBSNAT Minimum Data Set. Technical Report 2. Honolulu, Hawaii, USA: University of Hawaii.
IBSNAT (1990b). Documentation for IBSNAT. Crop Model Input and Output Files. Technical Report 5. Honolulu, HI: University of Hawaii.

IPCC-TGCIA (1999). Guidelines on the Use of Scenario Data for Climate Impact and Adaptation Assessment. Version 1. (Eds T. R. Carter, M. Hulme \& M. Lal), Geneva, Switzerland: WMO \& UNEP. Available online at www. ipcc-data.org/guidelines/TGICA_guidance_sdciaa_v1_final. pdf (verified 28 September 2010).

IPCC-TGICA (2007). General Guidelines on the Use of Scenario Data for Climate Impact and Adaptation Assessment, Version 2 (Ed. T. R. Carter), Geneva, Switzerland: WMO \& UNEP. Available online at www. ipcc-data.org/guidelines/TGICA_guidance_sdciaa_v2_ final.pdf (verified 28 September 2010).

Jones, C. A. \& KINIRY, J.R. (1986). CERES-Maize, a Simulation Model of Maize Growth and Development. Temple, TX: Texas A\&M University Press.

Jones, J. W., Hoogenboom, G., Porter, C. H., Boote, K. J., Batchelor, W. D., Hunt, L. A., Wilkens, P. W., Singh, U., Gijsman, A. J. \& Ritchie, J. T. (2003). The DSSAT cropping system model. European Journal of Agronomy 18, 235-265.

KAJFEŽ-BogATAJ, L. (1993). Impacts on future climate change on spring barley and maize yield in Slovenia. Journal of Agricultural Meteorology 48, 627-630.

KaJfEŽ-BogataJ, L. (1996). Effects of climate warning on CERES-Maize yield in Slovenia: sensitivity study. Research Reports of the Biotechnical Faculty of the University of Ljubljana 67, 11-18.

Kajfež-Bogataj, L. (1998). Potential crop shifts to higher altitude in Slovenia due to climatic change. In Proceedings of Agriculture and Forestry-Adaptability to Climate Change (Ed. M. Maceljski), pp. 143-152. Zagreb, Croatia: Croatian Academy of Sciences and Arts.

Katušin, Z. (2000). Climate Monitoring and Assessment for 1999. Reviews no. 9. Zagreb, Croatia: Republic of Croatia - Meteorological and Hydrological Service.

KLIK, A. \& EITZINGER, J. (2010). Impact of climate change on soil erosion and the efficiency of soil conservation practices in Austria. Journal of Agricultural Science, Cambridge 148, 529-542.

Lancashire, P. D., Bleiholder, H., van den Boom, T., Langeluddecke, P., Stauss, R., Weber, E. \& Witzenberger, A. (1991). A uniform decimal code for growth stages of crops and weeds. Annals of Applied Biology 119, 561-601.

Majdak, T., Petrov, V. \& Hrgović, S. (2007). Agrotechnical Practice of Maize Production (in Croatian). Zagreb, Croatia: Croatian Agricultural Extension Institute. Available online at http://www.hzpss.hr/adminmax/publikacije/kukuruz.pdf (verified 28 September 2010).

MeIER, U. (1997). BBCH-Monograph. Growth Stages of Plants. Entwicklungsstadien von Pflanzen. Estadios de las plantas. Deéveloppement des Plantes. Berlin, Germany: Blackwell Wissenschaftsverlag.

Mitchell, J. M. Jr., DzerdzeevskiI, B., Flohn, H., Hofmeyr, W. L., Lamb, H.H., RaO, K. N. \& Wallen, C.-C. (1966). Climatic Change. Report of a working group of the Commission for Climatology. WMO Technical Note 79. Geneva, Switzerland: WMO. 
Ritchie, J. T., Singh, U., Godwin, D. C. \& Hunt, L. A (1990). A User's Guide to CERES-Maize-V2.10. Muscle Shoals, Alabama, USA: International Fertilizer Development Center.

Sneyers, R. (1990). On the Statistical Analysis of Series of Observations. WMO Technical Note 143. Geneva, Switzerland: WMO.

Stipetić, I. (1991). Crop Production in Croatia-Historical Series 1885-1990 (in Croatian). Zagreb, Croatia: University of Zagreb.

Šimanović, M., Svetina, S., Capar, B., Mihajlović, M., ŽAnić, M. \& Domitrović, Z. (2008). Agriculture, hunting and forestry. In Statistical Yearbook of the Republic of Croatia (Ed. J. Crkvenčić-Bojić), pp. 248-277. Zagreb, Croatia: Republic of Croatia - Central Bureau of Statistics.

Tsuji, G. Y. \& Balas, S. (1993). The IBSNAT Decade. Honolulu, HI: University of Hawaii.

VučEtić, V. (2006). Report of the Pilot Assessment: Modelling of maize production and the impact of climate change on maize yields in Croatia. In Specific Support Action Introducing Tools for Agricultural Decision-making under Climate Change Conditions by Connecting Users and Tool-providers (AGRIDEMA) (Ed. J. Eitzinger), Vienna, Austria: Institute of Meteorology, BOKU. Available online at http://www.agridema.org/opencms/export/sites/ Agridema/Documentos/croatia_vucetic.pdf (verified 28 September 2010).
VuČETIĆ, V. (2008). Modelling of climate change and maize production in Croatia. In 18th International Congress of Biometeorology: Harmony within Nature (Ed. M. Iriki). CD-ROM, Tokyo, Japan: International Society of Biometeorology.

VuČETIĆ, V. (2009). Modelling of maize production and the impact of climate change on maize yields in Croatia. In Climate Variability, Modeling Tools and Agricultural Decision Making, Proceedings of the AGRIDEMA Workshop (Ed. A. Utset), pp. 195-201. Valladolid, Spain: ITACyL.

Wilkens, P. \& Singh, U. (2001). A code-level analysis for temperature effect in the CERES models. In Modeling Temperature Response in Wheat and Maize, Proceedings of a Workshop (Ed. J. W. White), pp. 1-7. El Batán, Mexico: CIMMYT.

Wolf, J. \& van Diepen, C. A. (1995). Effects of climate change on grain maize yield potential in the European Community. Climate Change 29, 299-331.

ŽAlud, Z. \& DubrovskÝ, M. (2002). Modelling climate change impacts on maize growth and development in the Czech Republic. Theoretical and Applied Climatology 72, 85-102.

Zheng, H. F., Chen, L. D. \& Han, X. Z. (2009). The effects of global warming on soybean yields in a long-term fertilization experiment in Northeast China. Journal of Agricultural Science, Cambridge 147, 569-580. 